\title{
Experiência de namoro e casamento em famílias de camponeses-migrantes
}

\author{
Marilda Aparecida de Menezes*
}

\section{Introdução}

Este artigo pretende analisar as memórias de mulheres camponesas do Agreste paraibano sobre namoro e casamento. É parte de uma pesquisa mais ampla sobre: "Memórias de Famílias de camponeses - trabalhadores migrantes (homens e mulheres) - 1950-1990", realizada entre 2001 e $2003,{ }^{1}$ em que foram realizadas entrevistas semi-estruturadas e histórias de vida de 34 pessoas, sendo 11 homens e 23 mulheres, conforme o quadro adiante. A grande maioria dos entrevistados tem idade entre 40 e 80

\begin{tabular}{|c|c|c|}
\hline Faixa etária & Masculino & Feminino \\
\hline $30-40$ & $0(0 \%)$ & $1(4 \%)$ \\
\hline $40-50$ & $2(18 \%)$ & $5(22 \%)$ \\
\hline $50-60$ & $5(45 \%)$ & $8(35 \%)$ \\
\hline $60-70$ & $3(27 \%)$ & $5(26 \%)$ \\
\hline $70-80$ & $0(0 \%)$ & $1(4 \%)$ \\
\hline 80 e + & $1(9 \%)$ & $2(9 \%)$ \\
\hline Total & $11(100 \%)$ & $23(100 \%)$ \\
\hline
\end{tabular}

* Professora do Programa de Pós-Graduação em Ciências Sociais da Universidade Federal de Campina Grande.

1 Contamos com o apoio do CNPq com uma Bolsa de Produtividade de pesquisa, no período de 20013 e com dois bolsistas de Iniciação científica - Maria Rodrigues e Lidia Arnaud. 
anos, com exceção de uma mulher que tem 31 anos; a infância e a juventude deste grupo, assim, ocorreu entre as décadas de 1920 e 1980.

A reprodução das famílias camponesas nas décadas de 1970-90 no Agreste Paraibano passou por transformações significativas. A produção das culturas de subsistência e algodão declinou, enquanto a pecuária cresceu, influenciando significativamente a sobrevivência dos camponeses, que se tornaram mais dependentes do trabalho assalariado. Este processo tem sido discutido em estudos sobre transformações agrícolas no Estado da Paraíba (Menezes, 1985 e 2002; Moreira e Targino, 1997). Estas mudanças também contribuíram para a expulsão de moradores para a periferia da área urbana do município. Embora sejam residentes urbanos, continuam a cultivar pequenos pedaços de terra em locais distantes de suas casas, passando à condição de rendeiros. A categoria de rendeiros inclui trabalhadores que vivem em "áreas urbanas" do município, aqueles que vivem na área rural e pequenos proprietários de terra insuficiente que também plantam em terras de outros. Os camponeses no município estudado, Fagundes, estado da Paraíba, são representados pelas três condições de acesso à terra e residência: os pequenos proprietários, os moradores que não possuem terra, mas trabalham e vivem na propriedade e os rendeiros. As três categorias têm acesso precário à terra e, conseqüentemente, trabalham em alguma outra atividade tal como pequenos negócios, emprego de meio período como servidores do município ou trabalho assalariado na localidade ou em outros lugares, como na área canavieira ou em cidades dentro ou fora da região Nordeste.

A memória é reconhecida por um número de pesquisadores em diferentes ciências como uma importante fonte de demarcação de identidades individual, familiar ou do grupo. Halbwachs (1990) entende a memória como resultado da interação social, por isso, ao invés de estudá-la em si, isolando-a no indivíduo e colocando-a cada vez mais distante do social, ele se propõe a analisar os "quadros sociais". A lembrança individual passa a estar relacionada com os grupos e instituições nas quais o indivíduo se inclui, tais como a família, a classe social, a escola, a igreja, ou o trabalho. O relato sobre o passado marca o pertencimento do indivíduo ao grupo, a continuidade dentro do tempo e o sentimento de coerência (Pollak, 1992). Tomando como referência essas perspectivas, o estudo da memória de homens e mulheres em famílias de camponesas contribui teoricamente para a compreensão de suas identidades. O estudo da 
memória não se limita a um resgate das experiências do passado, mas trata-se de uma re-significação deste passado à luz das experiências do presente, o que permite compreender a continuidade do grupo no tempo (Halbwachs, 1990 e Pollak, 1992).

Embora a memória seja social, como bem enfatiza Halbwachs, ela se concretiza quando mentalizada ou verbalizada pelas pessoas. Baseado neste argumento, Portelli prefere evitar o termo "memória coletiva" e propõe apenas o termo "memória", compreendida nos seguintes termos:

A memória é um processo individual, que ocorre em um meio social dinâmico, valendo-se de instrumentos socialmente criados e compartilhados. Em vista disso, as recordações podem ser semelhantes, contraditórias ou sobrepostas. Porém, em hipótese alguma, as lembranças de duas pessoas - assim como as impressões digitais, ou, a bem da verdade, como as vozes - são exatamente iguais [...]. Assim, a história oral alia o esforço de reconstruir padrões e modelos à atenção às variações e transgressões individuais concretas. (Portelli, 1997, p. 16).

Se Portelli chama atenção para as "variações e transgressões individuais", Bourdieu (1996) está preocupado em compreender como as consciências individuais operam através de um substrato coletivo ou de instituições de totalização e de unificação do eu. Ele encontra na noção de habitus o princípio ativo da unificação das práticas e das representações. E explica a narrativa na relação do habitus com um mercado:

[...] as leis que regem a produção dos discursos na relação entre um habitus e um mercado se aplicam a essa forma particular de expressão que é o discurso sobre si; e o relato de vida varia, tanto em sua forma quanto em seu conteúdo, segundo a qualidade social do mercado no qual é oferecido - a própria situação da investigação contribui inevitavelmente para determinar o discurso coligido. (Bourdieu, 1996, p. 189).

A idéia de mercado de Bourdieu se aproxima da colocação de Pollak sobre a relação entre memória e identidade. O que e como se relata se referencia pela imagem que o narrador tem de si mesmo e pelo desejo de 
responder à expectativa do outro - que pode ser o investigador ou outro a quem o discurso se dirige. Portanto, trata-se da identidade possível de ser construída no campo social onde se situa o narrador.

Há grande proximidade entre Bourdieu e Pollak ao compreenderem a construção da identidade através da memória como um jogo de negociações em um espaço demarcado por sujeitos sociais em posições diferenciadas. Assim, as brechas para as expressões individuais estariam definidas pelo espaço social em que se insere o narrador. Portelli, embora reconheça que a memória é uma possibilidade de reconstruir processos, modelos, e regras, está bastante atento às "variações e transgressões individuais".

A análise que desenvolvemos sobre namoro e casamento a partir da memória de mulheres ${ }^{2}$ busca compreender as representações e práticas vinculadas ao habitus do grupo estudado - as famílias de camponeses migrantes -, bem como as transgressões e as práticas de resistência às regras, modelos e valores sociais. Os homens e mulheres, além de narrarem a partir de sua posição de gênero, também se detêm de modo mais longo sobre determinados fatos, acontecimentos ou fases da vida, como é o caso da infância. Esta mesma variação na narrativa é identificada por Bosi:

A infância é larga, quase sem margens, como um chão que cede a nossos pés e nos dá a sensação de que nossos passos afundam [...]. O território da juventude já é transposto como passo mais desembaraçado. A idade madura com passo rápido. A partir da idade madura, a pobreza dos acontecimentos [...] (1994, p. 336-7).

Esta diferenciação no tempo e espaço da narrativa dedicado a uma fase da vida ou a um acontecimento é entendida por Barros (1997, p. 140)

2 A maioria dos homens narra de forma monossilábica, demonstrando bastante prudência em narrar sobre suas vidas conjugal e ou extraconjugal. Quando perguntados sobre a infância, eles falam com muita espontaneidade, mas quando entramos no campo das relações sexuais, e das extraconjugais, eles ora silenciam, ora dão respostas monossilábicas. Peixoto (1997, p. 149) também constata diferenças entre as narrativas de homens e mulheres acima de 60 anos: "Assim, nas pesquisas precedentes, a comparação entre os relatos femininos e masculinos revelou conteúdos bastante diferentes; as mulheres tinham, em geral, muitas estórias para contar; histórias de infância e juventude, de casamento e envelhecimento, longos relatos de vida... Para os homens, o que importava narrar era a vida de trabalho, o vazio da inatividade gerado pela aposentadoria. Sobre a família, o interesse volta-se para os filhos; sua educação e inserção no mercado de trabalho." 
como a "densidade variável interna a cada narrativa", que se associa, por um lado, à formulação de projetos ou mudanças importantes que ocorrem ao longo da trajetória de vida de cada indivíduo e, de outro lado, às perspectivas distintas de homens e mulheres.

Ao adotarmos a metodologia da história oral, entendemos que as entrevistas semi-estruturadas e histórias de vida realizadas não foram simples técnica, instrumento de pesquisa para coletar dados, informações, mas um discurso construído no processo de interação social entre pesquisador e informantes. Assim, nos orientamos por Bourdieu (1999) ${ }^{3}$ e Thomson $(2000)^{4}$, que entendem que qualquer referência a procedimentos de pesquisa não esgota as estratégias infinitas da prática de pesquisa. Uma boa forma de tratar dos problemas teóricos e práticos da metodologia de pesquisa é percorrer os caminhos trilhados na interação entre o pesquisador e os informantes (Bourdieu, 1999, p. 693). ${ }^{5}$ Essas interações são permeadas por relações de poder, mas podem, também, se constituir em um espaço de negociação de identidades, saberes, concepções, possibilitando situações de empoderamento dos informantes.

As histórias de vida de mulheres e homens fornecem um material rico que contempla não apenas a organização social, mas também valores e regras familiares. A história de vida individual é amplamente representativa da experiência do grupo. As mulheres e homens relatam sobre fatos que são não apenas relacionados à suas próprias vidas, mas também comuns a outras pessoas na mesma posição social. À medida que contam suas histórias, aspectos do trabalho na terra e na casa, educação de crianças,

3 "Muitas dezenas de anos de prática da pesquisa sob todas as suas formas, da etnologia à sociologia, do questionário dito fechado à entrevista mais aberta, convenceram-me que esta prática não encontra sua expressão adequada nem nas prescrições de uma metodologia freqüentemente mais cientista que científica, nem nas precauções anticientíficas das místicas da fusão afetiva. Por estas razões, me parece indispensável tentar explicar as intenções e os princípios dos procedimentos que nós temos colocado em prática na pesquisa cujos resultados apresentamos aqui” (Bourdieu, 1999, p. 693-4).

4 “À primeira vista, parece difícil discordar de conselhos de tanto bom senso. Contudo, os historiadores orais vieram a perceber, nos últimos anos, o fato crucial - derivado, em parte, da antropologia e de estudos sobre as comunicações e promovido por pesquisadoras feministas - de que a entrevista é uma relação que se insere em práticas culturais particulares e que é informada por relações e sistemas de comunicação específicos. Em outras palavras, não existe uma única "maneira certa" de entrevistar, e a maneira que o "bom senso" indica como "certa" para entrevistas com membros da elite política branca do sexo masculino pode ser completamente inadequada em outros contextos culturais" (Thomson, 2000, p. 48).

5 Para um melhor aprofundamento deste tema veja Menezes (2004). 
sexualidade, relações de vizinhança emergem como expressões das experiências individuais e do grupo. Para este artigo, nos concentramos especificamente nos fragmentos de memória que se referem às experiências de namoro e casamento em famílias camponesas. A seguir, faremos uma breve análise da conceituação de família.

\section{A discussão de família na literatura}

A organização da família tem sido objeto de inúmeros estudos, desde os mais clássicos como os de Gilberto Freyre e Antonio Candido de Mello e Souza e até estudos mais contemporâneos que revisitam determinadas teorias. Para Mariza Corrêa (1994), a família patriarcal no Brasil é colocada como um modelo de organização familiar que se adequa a todos os tempos e espaços. Esse tipo de organização familiar é tomado como a história homogênea de todas as gerações no Brasil, portanto, como um tipo fixo em que os papéis sociais são definidos, substituídos e reprodutores de um modelo hegemônico que se instala nas grandes unidades agrárias de produção - engenhos de açúcar, fazendas de criação ou de plantação de café. Esse tipo de família mantém-se através da incorporação de novos membros, como os parentes legítimos ou ilegítimos e os extensos clãs.

Para Corrêa (1994, p. 16), o modelo patriarcal não pode ser representativo de todo o Brasil, pois se originou dos interesses de um "produto típico da colonização portuguesa nos trópicos". Segundo a autora, a obra de Gilberto Freyre Casa Grande e Senzala (1933), como também o ensaio de Antônio Cândido The Brazilian Family (1951), defendem a ilusão de que o estudo da forma de organização familiar do grupo dominante, ou de um grupo dominante numa determinada época e lugar, é capaz de substituir as inúmeras histórias dos diferentes modos de organização familiar da sociedade brasileira. Ocorre nos dois trabalhos desses autores citados uma história homogeneizada, pois são situações bem localizadas no tempo e no espaço. Em Freyre, o espaço era a economia açucareira pernambucana nos séculos XVI e XVII; já em Cândido, se vivenciava a plantação de café dos séculos XVIII e XIX.

Freyre e Candido propõem modelos perfeitos de organização familiar - um modelo ideal de família que existiu aqui no Brasil do século XVI 
ao XIX, a partir da qual se deriva toda a formação social do Brasil. O que nos sugerem é que a formação colonial nestes 300 anos foi composta por duas partes: a família patriarcal e a outra que constituía a maior parte da população conhecida como "degradados". Para Corrêa, a história da formação da família patriarcal e a conjugal moderna deve ser questionada: a quem ou a que é interessante ser contada essa história como uma forma ideal de se constituir família? Portanto, é necessário se considerar outras formas de família que não a patriarcal, pois esta não é a única possível.

Corrêa tece críticas aos estudos clássicos sobre a família no Brasil em especial os empreendidos por Gilberto Freyre e Antônio Candido, que ela chama de "darwinistas sociais" - por tomar como referência a família patriarcal sem atribuir muita importância a outras possibilidades que se faziam presentes, mas com menor visibilidade. Corrêa questiona se a família patriarcal não teria sido um modelo ideal dominante que se sobressaía em meio a outras formas de família. Nesse sentido, a autora critica a homogeneização histórica elaborada pelos autores citados que, por se prenderem ao contexto do engenho - às oposições entre casa grande e senzala, senhor e escravo, núcleo familiar e massa anônima -, não consideraram outros contextos econômicos e formas de organização familiar. Este procedimento seria, para ela, utilizando as palavras de Gianotti (apud Corrêa, 1994): "instauração de uma história universal por meio da destruição das histórias particulares”. Ocorre, afirma Corrêa, que há várias formas de organização familiar inventando maneiras de suportar a dominação do modelo ideal da família patriarcal. Porém, isso não significa que essas últimas sejam formas marginais, como colocaram alguns autores da história da família brasileira.

Estamos de acordo com Cláudia Fonseca (2000) quando, numa perspectiva que se aproxima daquela proposta por Corrêa, sugere que se pense não em modelo de família variante e suas variantes, mas numa coerência interna às práticas que as tornam um "modelo alternativo":

Se a idade para o casamento, a diferença de idade entre os esposos, o espaçamento dos nascimentos, a divisão sexual de trabalho [...] e outras coisas mais mostram diferenças significativas, será que não devemos procurar a coerência interna dessas práticas [...] em vez de contentar-nos com o modelo dominante e suas variantes?" (Fonseca, 2000, p. 57). 
A referida autora realizou seu estudo em um contexto urbano, mas sua discussão acerca dos padrões familiares em suas particularidades nos serve de referência.

As famílias camponesas das comunidades estudadas são compostas por um homem e uma mulher unidos pelo casamento legal, religioso ou consensual, o que resulta numa prole numerosa. Há exemplos de famílias que apresentam agregados - sobrinho (a), irmão (a) ou mãe de um dos cônjuges. As famílias das comunidades estudadas são compostas por camponeses trabalhadores-migrantes que têm como base econômica a agricultura de subsistência complementada por outras atividades, como servidor público na prefeitura, pequeno comércio e, principalmente, a migração temporária dos homens. Uma das principais mudanças que a migração traz é a assunção da "chefia" da família - mesmo que provisória por parte da mulher para preencher a lacuna deixada pelo marido no gerenciamento da casa e do roçado e na educação dos filhos.

\section{O namoro}

O tema da família camponesa é recorrente nas etnografias clássicas sobre o campesinato no Brasil, tais como os trabalhos de E. Willems (1961) e A. Cândido (1977). No capítulo de seu livro intitulado Sexo e Família, uma das observações que Willems (1961, p. 56) faz a respeito do namoro é sua transição do privado, expresso através dos sinais, troca de flores para o público, dos passeios à noite, mãos dadas, acompanhadas de alguma irmã ou irmão mais velho.

Nas comunidades pesquisadas, as mulheres e os homens falam timidamente sobre namoro, sexualidade e casamento. No que diz respeito à sexualidade, o silêncio, a timidez e a vergonha constituem a linguagem predominante. Algumas relataram sobre a primeira menstruação. Durante a adolescência, as mulheres não falavam sobre as transformações pelas quais passavam seus corpos com suas mães. Algumas conversavam com amigas mais velhas que já haviam passado pela visita surpresa. Nas narrativas sobre o namoro, um tema recorrente foi o tipo de beijo permitido em público.

As mulheres negavam que houvesse beijo na boca ou qualquer aproximação corporal em ambientes públicos, o namoro era só olhar, ficar 
conversando na presença dos pais ou de outros membros da família que supervisionassem para não ultrapassar os "limites", deixando a moça "falada", como bem nos relata Dona Rita (42 anos):

M: Me diga uma coisa, como era o namoro naquela época?

D. Rita: $\mathrm{Na}$ época do meu namoro, era uma coisa muito simples, por causa que minhas irmãs eram do tipo de pessoa que tinha que namorar (ela perdeu a mãe com 5 anos e o pai aos 15 anos e morava com as irmãs mais velhas) com muito respeito, porque a moça tinha que se casar com muita delicadeza. Não podia avançar antes do casamento.

M: Como é um namoro muito simples?

D. Rita: Sentada junto um do outro só conversando assim na presença de todo mundo. Não podia ficar sozinha. Era assim... o namoro de que eu tive foi esse.

M: Não podia namorar fora de casa, não é?

D. Rita: Não, só se fosse o acompanhado.

M: e pegava na mão.

D. Rita: Pegava, pegava na mão assim elas não se incomodavam não.

M: E dava beijo na boca.

D. Rita: $\mathrm{Na}$ vista delas não, só se fosse escondido.

M: E dava escondido?

D. Rita: Dava.

M: E o que senhora chama de avançar antes do casamento?

D. Rita: Assim, no caso assim de hoje em dia que os jovens de hoje tem sempre assim, tem que ter uma relação sexual antes do casamento. E naquela época se acontecesse isso pra minha família era um escândalo, não podia acontecer, tinha que ter muito cuidado pra isso não acontecer. 
Dona Rita, embora enfatize que o namoro seguia as regras morais de "só pegar na mão" e namorar no espaço doméstico, relata a transgressão daquelas regras através do "beijo às escondidas". Esse comportamento, em geral, acontecia em espaços seguros, invisíveis, longe dos olhos dos pais e do controle da comunidade. As práticas do namoro que questionavam o que era socialmente instituído podem ser entendidas como práticas difusas, mas, muitas vezes, persistentes e recorrentes, de resistência às regras do namoro, constituindo o que Scott $(1985,1990)$ chama "práticas cotidianas de resistência". Estas brechas fazem com que o namoro não seja um modelo rígido de comportamento, mas tenha configurações diversas a partir das práticas e modos de pensar de seus praticantes, como bem nos ensina o conceito de experiência de Thompson (1981). ${ }^{6}$

Dona Tânia, 51 anos, também reafirma a não existência do beijo na boca em público:

L: E como era o namoro naquela época?

D. Tânia: Na minha época?

L: É.

D. Tânia: Não era como o de hoje, né? Que hoje eu acho uma coisa muito liberal. O pessoal fica muito ligado um no outro. Tá certo, o beijo sempre existiu, né?

L: Beijo na boca?

6 Por "experiência", nos inspiramos na noção proposta por Thompson (1981, p. 182): "O que descobrimos (em minha opinião) está num termo que falta: 'experiência humana'. É esse, exatamente, o termo que Althusser e seus seguidores desejam expulsar, sob injúrias, do clube do pensamento com o nome de 'empirismo'. Os homens e mulheres também retornam como sujeitos, dentro deste termo - não como sujeitos autônomos, 'indivíduos livres', mas como pessoas que experimentam suas situações e relações produtivas determinadas como necessidades e interesses e como antagonismos, e em seguida 'tratam' essa experiência em sua consciência e sua cultura (as duas expressões excluídas pela prática teórica) das mais complexas maneiras (sim, relativamente autônomas) e em seguida muitas vezes, mas nem sempre, através das estruturas de classe resultantes) agem, por sua vez, sobre sua situação determinada". O mais importante de apreender no conceito de experiência Thompsiana é o verbo tratar, pois o mesmo é colocado para designar o modo como os indivíduos elaboram e reelaboram, constrói e reconstrói seus sentimentos, sua maneira de agir, de pensar a partir da realidade na qual estão inseridos (Moraes e Menezes, 1999). A classe não existe apenas como grupo que se constitui a partir da posição no processo de produção, mas inclui sociabilidades, valores, expectativas de vida, lazer, etc. Ele nos leva a pensar sobre a necessidade de se analisar aspectos da vida social de determinadas classes sociais. 
D. Tânia: Não, no meu tempo não existia não!

L: Na época não tinha beijo na boca não?

D. Tânia: Não

L: Aí era só conversar?

D. Tânia: Era. Beijo no rosto! (risos)

O beijo na boca ainda escandaliza as mulheres da comunidade. Ao entrevistar Dona Zefinha, 48 anos, perguntamos sobre o beijo, ela ficou constrangida e perguntou a uma moça que estava na casa no momento, se ela beijava na boca. Quando essa respondeu que sim, Dona Zefinha ficou espantada e quis saber se "beijava na língua", ao que, para seu espanto, a visita respondeu que sim. Elas também falam sobre os beijos da televisão como sendo algo "nojento".

Pelas conversas que tivemos, percebemos que os homens têm liberdade para ir a festas e freqüentar lugares públicos, o que não é permitido às mulheres. Os pais não aceitavam que as filhas fossem às festas acompanhadas pelos namorados, então estes iam sozinhos e arranjavam outras namoradas. Disso resultavam namoros acabados e reatados muitas vezes, como foram os casos de Dona Tânia, 51 anos e Dona Terezinha, 48 anos, cujo namoro mais demorado foi com o seu atual esposo, o senhor Geraldo, com quem ela namorou cinco vezes:

L: Cinco vezes? Aí, como era? Namorava, acabava...

D. Tânia: É. A gente ficava namorando, aí acontecia dele sair para outros lugares, eu não ia, ele ia e arranjava outra [...]. Aí depois eu ia pra outro canto, arrumava outro. Mas no canto que ele ia, que ele tava só e eu tava só, tinha que ficar nós dois juntos.

Dona Tânia sorriu quando contou dos namorados - meu foi só 10 ! Isto nos surpreendeu, ela foi a única mulher que falou sobre um número grande de namorados, embora tenham sido efêmeros. Havendo essa "reclusão" das mulheres ao seio doméstico e não lhes sendo permitido o contato com o sexo oposto, elas têm o círculo de possibilidades reduzido, logo, os namoros rapidamente finalizam em casamentos. 


\section{Namoro, fuga e casamento}

É recorrente, para as mulheres, casar com o primeiro namorado. No entanto, nem sempre há possibilidades de preparar o ritual do noivado e do casamento, seja só no civil ou no religioso ou em ambos, recorrendo-se, com freqüência, à prática da fuga do casal por alguns dias e, em seguida, o reaparecimento e a realização apressada do casamento para a moça não ficar mal falada. A recorrência de fugas entre as mulheres entrevistadas foi uma surpresa para nós, pois sabíamos que isto ocorria, mas não com tanta freqüência, e por remeter-nos a décadas do início do século XX. Woortmann formula a hipótese de que a maior freqüência de fugas parece se relacionar a um processo de progressivo empobrecimento dos sitiantes, ainda que permaneça a distinção entre fortes e fracos (1992, p. 11-2):

Contudo, se a fuga é expressão de um processo de pauperização, ela é, também, pelo menos entre os sitiantes que estudamos, a expressão de padrões de troca matrimonial e valores relativos à honra da família e ao princípio de hierarquia. A historicidade inclui, pois, ao mesmo tempo, descontinuidades e continuidades. A própria fuga é um padrão; ela é uma continuidade através da qual se evitam descontinuidades. Se ela é, na aparência, uma ruptura, ela assegura uma continuidade. Se ela é histórica, como mostra Gnaccarini, é também tradição.

Várias mulheres e homens viveram a experiência do casamento através da fuga. Dona Janete, 60 anos, casou-se em 1959:

Acabou cinco vezes o casamento, por causa dela, dessa prima minha (se refere a uma prima que namorava, também, com seu marido). Aí depois pai disse que ficava ou não pra acabar com essa novela. Aí Antônio foi ajeitar o dia pra casar. Pai foi ajeitar uma casinha perto da dele. No fim a gente ficou foi junto, ajeitou o casamento pra fevereiro, aí ela soube, aí disse como ele ia casar com eu, que era prima dela, que não devia nada a eu, mas devia a ela. Nesse tempo tinha um homem que não era prefeito ainda, mas mandava em tudo, aí mandou chamar Antônio lá e perguntou: Você tá devendo a Maria? (prima de Dona Janete) 
Antônio disse: "Não, eu não devo nada a ela não, eu sou noivo da prima dela e vou me casar com ela, só que eu não tenho nada a ver com essa daí."

Aí mandaram perguntar se eu queria casar com Antônio na Igreja e ela no civil, eu disse: "de sócio já era, eu mesmo não quero não". Aí eu mandei Antônio ir na casa de João Figueiredo (o prefeito) que ele o protegia, então Antônio foi e contou a história e ele disse que era pra casar comigo. Aí ele foi e encontrou um amigo no caminho que trazia um bilhete, dizendo que era pra ele casar com Maria, aí ele foi e rasgou o bilhete jogou no mato e se escondeu, chegou em casa pegou o documento dele e se mandou pra terra dele - Imbuzeiro (risos).

Aí ele perguntou se eu queria casar mesmo com ele, porque se eu quisesse, ele ajeitava onde ele tivesse e mandava me pegar. Quando foi de noite chegou o pai e a mãe dele na maior agonia, dizendo que ele tinha sumido e tinha levado as roupas, aí eu contei pra onde ele tinha ido. No outro dia o velho me deu dinheiro pra eu ir. Ele mandou um bilhete dizendo que já tinha arrumado uma casa e eu mandasse o documento pra acertar o casamento, aí eu mandei dizer que queria. Com quinze dias a gente foi... chegando lá ainda passamos oito dias pra casar porque a mulher com o vexame tirou o batistério em uma data e o registro em outra. Tudo avexado assim, porque não era pra eles saber cá que a gente ia casar.

$\mathrm{Na}$ história de namoro de Dona Janete, 60 anos e Sr. Antonio, 65 anos, emerge um conflito amoroso com a prima de Dona Janete, numa disputa acirrada de quem conseguiria casar com Antonio. Este fato pode ser bem explicado pelo restrito número de homens no mercado matrimonial, cujo espaço, na maioria das vezes, se delimitava pelo sítio ${ }^{7}$ onde moravam ou estendia-se pelos sítios vizinhos. A decisão de se casar com Dona Janete ocorre rapidamente com a estratégia da fuga. No entanto, o pai de Dona Janete não aprovou inicialmente a atitude do genro, mas, posteriormente, abençoou o casal:

M: O que o pai da senhora achava dessa história?

D. Janete: Ele confirmava comigo, dizia que Antônio era um rapaz trabalhador, que ia ser um bom genro, aí ele disse que aceitava, 
aí a gente fomos. Foi nove pessoa daqui de Fagundes, chegamos lá passamos oito dia, casemos e fiquemos lá. Quando foi com um mês eu disse que vinha em casa, porque toda noite eu sonhava com pai. A gente veio, quando chegou aqui a dona (a prima de Janete) viu ele e deu parte dele, aí mandaram chamar ele e prenderam ele e disseram que ele tinha fugido e não tinha casado com ela, ele ia passar o que tinha pra ela. Ele tinha uma casinha de taipa (risos), aí ele foi chegou lá ficou preso. Aí eu fui na casa de Zuca Ferreira (o chefe político local) falei com ele, aí ele foi e soltou, aí a gente foi embora pra Umbuzeiro. Abriu o processo e passaram a casa pra ela. Depois a gente voltou pra Fagundes e foi começar a vida, fomos trabalhar na agricultura. Nasceu o primeiro, o segundo e o terceiro menino e eu trabalhando, depois quando eu tava com dois meninos, José Fernando (mais velho) foi ajudar o pai a plantar, aí José tinha medo de lagartixa (risos), quando ele via uma lagartixa dentro do rancho sai correndo, eu via a hora ele se espertar, aí trazia de novo pra dentro do rancho e era aquela agonia.

Outro caso de casamento por fuga é relatado por Dona Paizinha, de 65 anos, que se casou em 1956:

M: E quando foi pra senhora conheceu seu esposo, como foi?

D. Paizinha: Quando foi pra conhecer ele, eu tenho um tio que era casado com uma irmã dele, aí comecei ver ele na casa da minha cunhada. Ela era cunhada da minha mãe, casada com meu tio, aí começamos a se ver lá. Se gostemos, ele parece que não gostou de mim, saiu fora, saiu fora de mim né. Ai eu disse que ia arrumar outro, ai arrumei outro, ele chegou pegou uma reza comigo. Ai quando foi... voltemos a se namorar de novo, ai não acabou-se não, passamos quatro anos, quatro anos para casar, aí terminamos a casar roubado.

7 Sítio é um território de parentesco, como bem identificam Woortmann, K. e Woortmnn, E. (1992, p. 3) para o caso de Sergipe, onde ocorre o casamento preferencial entre primos, de modo a preservar o patrimônio, no caso, a terra. "Em Sergipe, mesmo entre camponeses parcelares não organizados em sítios, o casamento entre primos é também considerado preferencial, pois a preservação do patrimônio é um princípio fundamental de reprodução social”. 
M: Oxente! Ele carregou a Senhora?

D. Paizinha: Carregou minha filha.

M: Foi, mesmo.

D. Paizinha:: Carregou eu, eu... já que a gente tem que falar a verdade né.

M: É!

D. Paizinha:: Eu não vou falar mentira, eu já era mulher dele, aí ele me carregou pra casa da mãe dele, ai meu pai não...

M: Antes de carregar, a Senhora já era mulher dele?

D. Paizinha: Já!

M: Ah! sim.

D. Paizinha: Aí ele foi pro Rio, quando ele chegou do Rio carregou, casei lá na casa da mãe dele, meu pai ficou dezesseis anos intrigado, quinze anos, quando meu pai veio falar com ele, essa menina tava com quinze ano, minha filha, minha filha mais velha, tá com quarenta e um ano, ai meu pai fala com ele, mais fala... mais parece que eles não se une bem não, né, a gente conhece.

Embora a virgindade fosse um valor sagrado, relações sexuais já ocorriam antes do casamento, como nos relata Dona Paizinha, que namorou em finais da década de 50. Assim, não apenas beijos aconteciam às "escondidas", mas, também, o ato sexual, o que, para as mulheres, definia o seu pertencimento ao homem, como diz Dona Paizinha: "eu já era mulher dele". A fuga foi apenas uma estratégia de viabilizar o casamento, que estava se postergando 8 já por quatro anos, mas, por falta de recursos, o casal não conseguia realizá-lo segundo as regras sociais. No caso de Dona Paizinha, o pai não foi de acordo com o casamento, mas ele se realizou

8 A fuga entre os pequenos produtores paulistas (estudados por Gnacarini (s/d.) não difere essencialmente daquela por nós observada entre os sitiantes fracos. Não se trata da negação de um casamento desejado pelos pais, nem da afirmação de uma união por eles recusada. Como se viu, ela é antecipada pelo namoro na casa dos pais da noiva. Trata-se, pelo contrário, de uma forma de realizar o casamento. Não só isso, mas, no caso de Sergipe, de realizar o casamento preferencial" (Woortmann, 1992: 17). 
na casa da sua sogra. A fuga para a casa dos pais do noivo é um padrão recorrente do ritual da fuga, como bem explica Woortmann (1992, p. 14):

Se os noivos fogem, para onde vão? Contrariamente ao que se poderia pensar, não se dirigem rumo a destino ignorado, ou aleatório. Muito pelo contrário, rumam para onde se espera que fossem, isto é, para a casa do pai do rapaz, de um seu parente, freqüentemente padrinho, ou mesmo de um parente em comum, já que o casamento tende a ser entre primos.

Muitas vezes, a fuga para o casamento acontece quando os pais não concordam, como foi o caso de Dona Paizinha, 65 anos, e dona Zefinha, 41 anos, que se casou com o Sr. José de Lima. Dona Zefinha falou que teve que fugir com seu atual marido para poder se casar, pois os pais não admitiram o namoro com um homem que já tinha sido casado. No período que realizamos a entrevista, no ano de 2002, Dona Zefinha estava sofrendo uma crise emocional porque sua filha de dezesseis anos havia também fugido para efetivar uma união conjugal que não seria aceita pelos seus pais, devido à filha ser muito jovem para o casamento. Segundo sua mãe, ela deixou para trás estudos, família e a promessa de uma vida diferente daquela trilhada pela mãe. Aliás, não sabemos dizer se doía mais a saudade da filha ou o investimento num caminho mais frutífero no qual a mãe apostou.

L: Dona Zefinha, como era a experiência de namoro, naquela época?

D. Zefinha: A experiência de namoro, minha filha, era... a gente era uma pessoa tão sofrida que a gente.. assim... se a gente... pronto, no caso, meu caso mesmo, hoje eu disse a minha filha, eu disse: "Ó, minha filha, no tempo, eu fugi com seu pai, por quê? Porque meu pai nem minha mãe não me deu oportunidade nenhuma, né? Porque no caso, olhe, eu sofria muito, e outra que ninguém queria. Mas no seu caso, que foi primeiro namoro, né?”. Era uma experiência que... eu mesmo não tinha experiência de namoro não! Prá gente tava tudo bem, era uma coisa... sei lá...

M: Ninguém queria por quê, dona Zefinha? 
D. Zefinha: Porque ele já tinha sido casado, sabe?

M: Ah! $\operatorname{sim} .$.

D. Zefinha: Ele era separado da mulher, aí pronto! Ninguém queria, nem meus irmãos, nem nada! Não queria.

A fuga de Dona Zefinha foi a alternativa encontrada para viabilizar o casamento, pois não contava com o consentimento do pai e dos irmãos. A fuga para o casamento também aparece no contexto em que narra sobre a relação com o pai e mãe:

L: Dona Zefinha, a senhora poderia falar um pouco sobre a sua infância, como foi o trabalho para a senhora, as brincadeiras?

D. Zefinha: A minha infância foi assim, trabalhava assim, na roça, num sabe? E... num estudava, trabalhava só e brincava, assim, de casinha, não tinha brinquedo, não tinha nada, sabe? E meus pais não era assim, de abraçar um filho... eles também eram umas pessoas que também... eles não receberam isso dos pais deles, né? Aí também não deram pra gente. Aí pronto, fiquei, aí a infância da gente foi muito assim, sem... sei lá, a infância da gente foi muito diferente da de hoje. Eu tava dizendo às meninas, elas hoje tem tudo, pra vista da minha vida, elas hoje tem... tem tudo o que eu não tive, né? Aí pronto, minha vida foi... sei lá... Eu não gosto de falar disso não, visse! Minha infância foi tão ruim que eu lembro, mas não quero falar não!

Aí, com o tempo, meu pai não deixava assim... ele nem dava nada a gente, assim, a gente trabalhava na roça, chegava final de ano, assim, ele não dava roupa pra gente, não dava nada, aí teve uma vez que eu fugi pra trabalhar em casa de família, que ele não deixava não, sabe? Aí, passei um tempo trabalhando, depois voltei pra casa, aí passei um tempo em casa de novo, aí não agüentei de novo, que meu pai era desse povo ignorante, sabe? Se a gente arranjasse, assim, um namorado e trouxesse pra casa ele ficava xingando, dizendo coisa... e assim a gente tudinho saímos de casa logo, fugindo... fugi pra trabalhar, depois fugi com esse, com José, que ele não queria o casamento, aí eu fugi com ele, e... foi isso só! 
A incompletude das frases, como "eles também era umas pessoas que também...", ou "Aí pronto, fiquei, aí a infância da gente foi muito assim, sem... sei lá..." mostra a dificuldade de Dona Zefinha contar sobre sua relação afetiva com o pai, que não era muito carinhoso. Mas, ela vai tomando coragem e, posteriormente, na sua narrativa declara abertamente: "Eu não gosto de falar disso não, visse? Minha infância foi tão ruim que eu lembro, mas não quero falar não" .

Em várias narrativas das mulheres sobre a "relação afetiva com os pais", há textos de ressentimentos, imagens negativas do pai, mas, raramente, sobre a mãe. ${ }^{9}$ A saída de casa para trabalhar é representada por Zefinha como "fuga" do controle autoritário do pai, que controlava o trabalho dos filhos na produção agrícola, mas não cumpria com a distribuição da renda familiar segundo o costume da organização social da família camponesa, no caso, suprir as filhas com roupa nova no momento da colheita ou por ocasião dos festejos, juninos ou de natal. ${ }^{10}$

As mulheres entrevistadas vivenciaram sua juventude entre as décadas de 1930 e 1970. Observamos que a escolha do conjugue é do interessado e não mais dos pais, como ocorria em princípios do século XX. Este mesmo padrão foi identificado por Willems e Cândido em suas pesquisas sobre o campesinato paulista nas décadas de 1940 e 50. Cândido diz:

Atualmente a situação mudou bastante (refere-se ao padrão do pai escolher o cônjuge para os filhos de ambos os sexos) e a iniciativa matrimonial parte do interessado; mas a vontade do pai é decisiva, sobretudo para as mulheres. Contra ele, as moças não ousariam decidir-se, e nesses casos a única solução é, para as mais afoitas, a fuga, seguida de casamento na polícia - o que às vezes se faz por esperteza, segundo dizem, para poupar o gasto do ato civil (Cândido, 1977, p. 232).

\section{E Willems:}

A despeito da relativa liberdade de escolha, o consenso paterno continua desempenhando um papel de relevo. Nas entrevistas

9 Uma análise mais ampliada desse ponto está em Menezes, 2007.

10 Sobre a divisão do trabalho familiar veja Heredia, 1976 
realizadas com pessoas de várias classes sociais, verificamos que a comunidade responsabiliza sobretudo o pai da esposa no caso de ser "infeliz" o matrimônio (Willems, 1961, p. 59).

Outros casamentos são decididos pelas adivinhações realizadas nos festejos juninos, como nos relata Dona Hosana, que aos 18 anos casouse com um viúvo de 54 anos, em casamento decidido por um jogo de adivinhação realizado nos festejos de São João.

Outra prática muito recorrente é, após o noivado, o noivo migrar para o Rio de Janeiro ou São Paulo para conseguir ganhar algum dinheiro e, assim, preparar o casamento. Isto tem sido uma prática recorrente em todas as décadas pesquisadas e persiste até o momento entre os jovens homens da região. Dona Terezinha, 62 anos, casou-se em 1963, aos 19 anos de idade. Seu noivo viajou após o noivado:

M: Oh, Dona Terezinha, aí como foi assim na época do namoro, noivado da senhora? Como foi que a senhora conheceu seu José?

D. Terezinha: Ah! Meu Deus do céu. Eu saí lá do Lavrador, vim pra aí, fiquei trabalhando numa terra dum homem; ele morava de frente da terra do lado de cá e eu morava lá do cercado de baixo. Eu cheguei ali passei um ano sem conhecer ele, passou bem um ano, aí eu conheci ele, aí a gente noivou, aí ele foi embora pro Rio, aí ficou lá no Rio quase dois anos, escrevia muito, quando foi a depois, aí eu cheguei, mandei acabar o casamento, acabou, eu não mandei acabar porque a mãe dele pediu pra eu não acabar, se não ele não vinha. Aí eu cheguei e não mandei acabar, esperei ele chegar, quando ele chegou, aí fui, acabei entreguei a aliança, aí a depois não sei o que foi que deu lá, a gente ajustou novamente.

M: Porque a senhora acabou?

D. Terezinha: Eu acabei porque eu arrumei uns namorados, sabe? E a mãe dele não achou bom, aí eu, também, peguei e acabou-se o casamento aí quando foi depois, com bem uns dois meses aí ajuntou novamente. Ele chegou no mês de novembro, foi no dia da Conceição, aí foi botou roçado, trabalhou e aí quando foi mês de agosto a gente casou; eu já tinha um bocado de troço, porque 
eu trabalhava e ia comprando, gostava de criar também, aí no instante ele lucrou e arrumou uma casa, a gente casou. Assim como pobre mesmo, fomos morar na terra dos outros, as coisas era tudo fraquinha que ele comprou lá em Campina na feira, mas graças a Deus, com o tempo a gente fomos comprando outras coisas e assim, graças a Deus, nunca me separei dele, só assim quando ele ia pro Rio, nunca me separei dele.

O fato de o namorado de Terezinha ter colocado roçado no período de inverno é um símbolo do planejamento do casamento, que se realiza em agosto.

Sr. José Possiano, após o noivado com D. Maria, 43 anos, também migra para o Rio de Janeiro para preparar o casamento.

M: Você podia falar um pouco sobre o seu namoro, seus namoros da juventude?

D. Maria: Meu namoro foi pouco, prá falar a verdade nunca tive namorado, ai aparecia eu tinha medo porque os rapazes que apareciam eu achava que não combinava comigo, porque aqui no interior é assim, quando o rapaz tem uma vaca, você tem que casar pela vaca, que ela tá querendo, se aproxima, pelo aquele bem financeiro, eu sempre tive medo disso, ai foi ficando, quando eu tava com 15 anos ele apareceu.

M: Ele foi seu primeiro namorado?

D. Maria: Maria: Não tinha muitas paquera por ai, foi rapaz do carão como se diz, porque a moça que né, eu queria mais sempre ficava dando serão como se diz.

M: Mas tuas paqueras eram como, eram só dar uma olhadinha?

D. Maria: É, só uma olhadinha, conversa de mentira.

M: Como era o namoro daquela época?

D. Maria: Era só conversar, jantar, podia os dois numa sala, ficava alguém na sala com a gente.

M: Se fosse pra sala ia alguém, se fosse pra calçada ia alguém? 
D. Maria: Não, porque não tinha calçada, podia ir pra festa, ia acompanhada.

M: Mas não tinha nem uns beijinhos naquela época?

D. Maria: Tinha nada, só no sufoco.

M: E o namoro com Severino, como era?

D. Maria: Aí foi dois meses. Aí noivou foi embora (migrou para o Rio de Janeiro) com um ano e seis meses, ele voltou pra casar. Pra mim ele não vinha mais, porque eu não sou insegura sabe, ele tem que vim, foi ficando sempre e depois ele chegou e me pediu.

M: Ele foi pra se preparar pro casamento?

D. Maria: Foi, pra terminar de se preparar, porque ele já tinha a casa, aí só faltava os móveis, aí nós trabalhamos pra juntar.

M: Aí nesse tempo que vocês noivaram, e ele foi pra lá, você não quis namorar?

D. Maria: Eu mesmo não. Deus me livre, foi só com ele, esperando.

M: E as pessoas o que diziam todo esse tempo?

D. Maria: Ficava em casa lavando prato, cuidando.

M: Mas os vizinhos perguntavam muito?

D. Maria: Não, porque eu fui uma pessoa muito individual. Me chamam de chata, porque eu sempre soube ajudar qualquer um na hora certa, mas pra mim tá, aí fulano, não sei o que eu era aquela pessoa parada, não dava satisfação.

A migração do homem na fase entre o noivado e o casamento é uma estratégia recorrente entre camponeses. Muitos deles já iniciaram sua carreira migratória antes do noivado, trabalhando no corte de cana de açúcar em Pernambuco ou no Rio de Janeiro, São Paulo ou Brasília. Esta prática se mantém até os dias atuais entre os jovens homens que migram, retornam e arranjam uma namorada, noivam e voltam a migrar para preparar o casamento. 


\section{O casamento em famílias de homens que migram}

O casamento nem sempre é realizado no civil e no religioso. Dona Zefinha, como relatamos, fugiu com Sr. José de Lima e não casou no civil nem religioso, porque ele não se divorciou da mulher anterior. Dona Tânia casou no civil, mas não no religioso. O que parece vantajoso no casamento civil é que ele legaliza a união em termos institucionais e não requer tantos gastos, como o ritual do casamento religioso, como relata dona Tânia:

L: Aí a senhora casou no civil e no religioso?

D. Tânia: Só casei no civil, até hoje.

L: Não quis casar no religioso não?

D. Tânia: A maioria das pessoas aqui só casa mais no civil !

Ela justificou o casamento religioso como sendo uma representação diante de Deus, mas já que está casada há muito tempo (22 anos), sua união já foi abençoada.

Uma outra variação é o casamento no civil seguido de um intervalo de meses para o casamento na igreja. É como se tivessem urgência de mostrar à comunidade que são casados, sentindo a benção divina entre eles e só depois confirmando para a mesma comunidade. Quanto às formas de casamento, não foi possível a partir das narrativas das mulheres identificar quantos foram no religioso, no civil ou em ambos. Este dado poderia ser interessante para termos uma idéia dos tipos de casamento, no entanto, a preocupação maior da pesquisa ao utilizar predominantemente narrativas de mulheres e homens foi compreender os significados, interpretações que os mesmos constroem de sua trajetória de vida.

A narrativa, ao ser o entrecruzamento entre a experiência individual e a social, é uma excelente fonte de compreensão de como os padrões institucionais, regras morais e costumes orientam as ações e pensamentos dos indivíduos. Mas, ao representar o diálogo entre o vivido e o interpretado, é também uma fonte rica de expressão das subjetividades, dos desvios das regras sociais, de inúmeras práticas difusas, invisíveis, microbianas (Scott, 1985, 1990) que são constituintes da experiência de infância, de adolescência, de casamento, de velhice dos homens e mulheres camponesas. Os significados diversos atribuídos às regras e valores sociais 
constroem uma diversidade de tipos de famílias, embora um modelo ideal baseado no casamento oficial e religioso permaneça como uma referência nas práticas e discursos sobre casamento e família.

$\mathrm{Na}$ década de 1970 houve a expansão da agricultura canavieira na Zona da Mata Nordestina, o que intensificou a contratação de trabalhadores migrantes. A região do Agreste da Borborema foi tradicionalmente, desde pelo menos a década de 1920, uma região de migração sazonal para a agricultura canavieira na Mata Seca do Estado de Pernambuco. Apesar da longa tradição do sistema de trabalho migrante, ocorreu uma intensificação da contratação dos trabalhadores migrantes localmente chamados de corumbas nas décadas de 1980-90. Além da migração para o corte da cana, os camponeses do Agreste da Borborema também tradicionalmente migram para cidades da Região Sudeste do Brasil. ${ }^{11}$

A migração tornou-se uma prática social inscrita no cotidiano dos espaços rurais do Nordeste, fazendo que, desde o início dos relacionamentos, as mulheres já se preparassem para a ausência do esposo. A ausência do marido e, posteriormente, do pai como uma estratégia histórica de reprodução social do campesinato no Nordeste, é representada pelas mulheres e filhos (as) através de uma atitude de conformismo, resignação, naturalização. As mulheres não lamentam, são capazes de suportar as agruras da separação, porque sabem que os maridos partiram em busca de recursos para garantir a sobrevivência da família.

A distância que separa os casais em determinadas épocas - durante as migrações - dá vazão ao discurso de que o homem precisa satisfazer

11 Tratando desse tema a literatura geralmente explica a intensificação da contratação de trabalhadores migrantes como resultado de diferenças entre a quantidade de trabalho requerido durante as fases do ciclo agrícola da cana de açúcar. Durante a colheita, um número grande de trabalhadores é requerido em comparação com fases de cultivo e da limpeza da cana de açúcar e este trabalho que não poderia ser intensivo de trabalhadores migrantes é o resultado da racionalização e controle da usina, pois são mantidos isolados dentro da propriedade da usina e aceitam novas normas e regras mais facilmente do que os locais (Novaes, 1993). As trajetórias individuais dos homens se caracterizam por movimentos múltiplos, onde se combinam o trabalho na agricultura canavieira em Pernambuco com migrações para as regiões metropolitanas do Sudeste, principalmente o Rio de Janeiro. As mulheres casadas não migram para a Zona da Mata Pernambucana, permanecem em casa cuidando do trabalho na terra, da casa e das crianças. No entanto, as mulheres solteiras migram para cidades próximas do município de origem, como o caso de Campina Grande, que fica em torno de $30 \mathrm{~km}$ de Fagundes ou se dirigem para cidades mais distantes da própria Região Nordeste ou Sudeste, em geral, trabalhando como empregadas domésticas. A migração circular dos homens, ao longo de várias gerações, transforma as mulheres em chefes de família durante a ausência masculina, embora o homem tende a manter o compromisso com a família que fica. 
suas necessidades sexuais, então acabam arranjando outras mulheres quando viajam. Essas relações extraconjugais dificilmente são assumidas verbalmente diante da mulher, mas são insinuadas, desde que insistamos na questão. Caso a mulher não esteja ouvindo, eles confessam mais facilmente.

Entre as reações das mulheres, é comum o velho dito popular: "O que os olhos não vêem o coração não sente". Elas afirmam ter ouvido rumores de que seus maridos tiveram ou têm envolvimentos com outras mulheres durante o casamento, mas só acreditam se elas vêem diretamente ou se forem vistos por parentes ou amigos. Outras dizem que não querem nem saber se é verdade ou não, tentando dissimular o fato para evitar uma possível separação conjugal.

No período em que os homens se ausentam, as mulheres assumem o papel de chefes de família, multiplicando esforços materiais e simbólicos para manter a produção agrícola, o suprimento das necessidades materiais da família e a orientação moral e emocional dos filhos. ${ }^{12}$ As mulheres relatam que durante o período de migração de seus maridos, elas trabalham no roçado, cuidam dos filhos e administram o dinheiro que o marido manda para honrar os compromissos. Nessa ocasião os filhos a respeitam e reconhecem a autoridade que elas impõem. Sarti, ao analisar a moral da família pobre num bairro da Zona Leste de São Paulo - São Miguel Paulista - verificou que a família funciona como referência simbólica para os pobres, é "pensada como uma ordem moral, constitui o espelho que reflete a imagem com a qual os pobres ordenam e dão sentido ao mundo social" (Sarti, 1996, p. 4). Nos casos estudados, a autora percebe que a mulher, ao assumir a responsabilidade econômica da família, passa a assumir também a autoridade e assim é percebida como chefe. Esta posição conferida à mulher não contém a autoridade que é característica do homem, já que ela lhe é atribuída devido ao papel de intermediário com o mundo externo, que ele exerce. Quando a mulher dispõe ou conquista essa autoridade e assume um papel central na família tem-se, segundo o caso em questão, um "arranjo compensatório".

Embora se tratem de contextos distintos - o de Sarti e o nosso cremos que há uma lógica semelhante que dá sustentação à assunção geralmente temporária - do papel de mulher chefe de família. Se no estudo da autora em questão a mulher passa a ter um papel ativo porque o homem

12 Para uma análise mais ampliada sobre este tema ver Menezes, 2002, Cap. 3 
fracassou no seu papel, no caso das mulheres camponesas acontece algo parecido. Ela assume a chefia não porque inverteu a hierarquia, mas porque foi (é) preciso preencher a lacuna deixada pela ausência temporária do marido. Mas quando o marido está presente, sua posição é secundarizada em relação ao homem. Dona Joana, 43 anos, é um exemplo da mudança de posição durante a migração do marido e na sua presença no lar. Ela vende roupas íntimas, cosméticos, gerencia uma mercearia, é merendeira de grupo escolar (vizinho à sua casa) e cuida do roçado. Além disso, está à frente do lar, cuidando de sua mãe e das duas filhas. Com a renda obtida dessas atividades, ela poderia desfrutar de uma autonomia com ou sem o marido, mas isso não ocorre.

Quando a visitamos durante a ausência dele, ela parecia mais "dona da situação", se portava com autoridade, falava sem embaraço, apesar da tensão gerada pelo controle de impressões. ${ }^{13}$ Em outra ocasião, quando seu marido tinha voltado de viagem, ela se mostrou ainda mais reservada que de costume, demonstrando um ar de subserviência com relação a ele.

Vê-se, pois, que a autonomia feminina não depende apenas de uma autonomia financeira, está para além disso, há uma moral por trás de uma construção social que, em certos momentos, parece inabalável, porém é flexibilizada frente a algumas circunstâncias. Dona Tânia, 51 anos, casada com o senhor Luiz, 54 anos, conversou tranqüila e abertamente conosco. Em visita anterior tínhamos entrevistado seu marido e ela estava presente, mas ficou em silêncio, só ouvindo. Quando fomos entrevistá-la a fim de complementar algumas questões do senhor Luiz, interrompeu várias vezes. Além dos afazeres domésticos - conta com a ajuda de sua filha mais nova para isso - ela "toma conta do roçado" e trabalha num grupo escolar.

Chamou-nos a atenção o comportamento de dona Tânia em casa e na rua. Ao chegarmos em Fagundes a vimos na rua e fomos falar sobre a possibilidade de entrevistá-la em sua casa. Ela respondeu afirmativamente, mas foi muito "seca". Quando lá chegamos, no entanto, ela foi extremamente receptiva e desinibida. No curso de nossa entrevista, perguntávamos sobre as decisões relacionadas aos filhos e a casa na presença e ausência de Sr. Luiz. Quando ele está fora tudo é decidido por ela, então perguntamos:

13 Para um detalhamento maior deste ponto veja o artigo Menezes et al (2004) "Interações sociais no trabalho de campo". 
L: Quando ele [Seu Luiz] chegava continuava do mesmo jeito ou vocês conversavam, decidiam juntos, as coisas?

D. Tânia: Decidia junto porque até hoje, tudo o que eu vou fazer, eu sempre passo pra ele, né? Eu nunca fiz assim, qualquer coisa, aqui não tem nada escondido entre eu e ele e os filhos. $\mathrm{O}$ que acontecer, tudo ele sabe. Não tem nada escondido, nem dele nem dos meus filhos. Aconteceu isso e isso. Eu jogo a carta na mesa!

Dona Joana, 43 anos afirmou que durante a presença de seu esposo é um bom período porque ele a ajuda:

M: Você sente que muda muita coisa na sua rotina quando seu esposo está aqui? $\mathrm{O}$ seu trabalho, a casa...

D. Joana: Fica melhor um pouco porque ele me ajuda, no trabalho, no campo, porque ele não ta, eu é que tenho que administrar, mesmo tendo pouco, mas tenho que saber pra onde vai cada centavo, como se diz, né? É tudo que passa pela minha cabeça.

Durante a ausência do esposo, as mulheres tendem a assumir toda a responsabilidade sozinhas, mas quando de seu retorno compartilham as dúvidas, os problemas, o trabalho. Em parte pelo respeito à autoridade do marido, mas também, pela necessidade de dividir o fardo que é carregado durante tanto tempo sem o companheiro.

Como havíamos colocado anteriormente, não estamos interessadas em apresentar um padrão de família, mas as variantes que se nos apresentam de acordo com as práticas internas às comunidades. Desse modo, temos famílias em que o homem tem sua autoridade reconhecida, embora a mulher passe a maior parte do tempo agindo como chefe da mesma.

Tratam-se de famílias onde as mulheres são socializadas no trabalho pesado - roçado, afazeres domésticos, etc., tarefas típicas do gênero masculino - e ao mesmo tempo são alvo de uma educação em que elas não podem se expor, não podem ter um contato mais constante e duradouro com a esfera pública - não têm escola, não podem ir a festas... No entanto, quando adultas, estão imersas num universo onde a fronteira entre atividades masculinas e femininas são tão fluidas quanto o "trânsito" dos homens para as regiões de migrações. 


\section{Referências bibliográficas}

BARROS, M. M. L. Densidade da memória, trajetória e projeto de vida. Estudos Feministas. Rio de Janeiro, IFCH/UFRJ , v. 5, n. 1, p. 140-147, 1997.

BENMAYOR, R. and Skotnes, A. Some reflections on migration and identity. In: BENMAYOR, R.; SKOTNES, A. (ed.). Migration and Identity. International yearbook of oral history and life stories. Oxford: Oxford University Press, 1994. v. III, p. 1-18.

BOSI. Ecléa. Memória e sociedade: lembranças de velhos. São Paulo: Companhia das Letras, 1994.

BOURDIEU, P. A miseria do mundo. $3^{\mathrm{a}}$ ed. Petrópolis: Vozes, 1999;

A ilusão biográfica. In: Usos e abusos da história oral. FERREIRA, M. M. (org.) Rio de Janeiro, Ed. FGV, 1996, p.183-192.

CANDIDO, A. Os parceiros do Rio Bonito. 4a . ed. São Paulo, Livraria Duas Cidades, 1977.

CORRÊA, Mariza. Repensando a Família Patriarcal Brasileira: Notas para o estudo das formas de organização familiar no Brasil. In: ARANTES, Antônio A. et al. Colcha de retalhos: Estudos sobre a família no Brasil. Campinas, Ed. UNICAMP, 1994.

FONSECA, Cláudia. Família, fofoca e honra: etnografia de relações de gênero e violência em grupos populares. Porto Alegre: Ed. UFRGS, 2000.

GNACARINI, J. C. O rapto das donzelas. Mimeo. s/d.

HALBWACHS, M. A memória coletiva. São Paulo: Editora Vértice, 1990.

MENEZES, M. A.; AIRES, L. M.; SOUZA, M. R. Construindo narrativas orais: interações sociais no trabalho de campo. Cadernos de Campo. São Paulo, n. 12, 2004.

MENEZES, M. A. Redes e enredos nas trilhas dos migrantes. João Pessoa / Rio de Janeiro: Ed. UFPB / Relume Dumará, 2002.

MOREIRA, Emilia; TARGINO, Ivan. Capitulos de Geografia Agrária da Paraíba. João Pessoa: Ed. Universitária, 1997.

NOVAES, J. R. P. Modernização e relação de poder: transformações na agroindústria canavieira no Nordeste do Brasil. Proograma em Economica da Universidade Estadual de Campinas. Tese de Doutorado. 1993.

PEIXOTO, C. E. Histórias de mais de 60 anos. Estudos Feministas. Rio de Janeiro, IFCH/ UFRJ, v. 5, n, 1, p. 148-158, 1997.

POLLAK, Michel. Memória e identidade social. Estudos Históricos. Rio de Janeiro, CPDOCFGV, v. 5, n. 10, 1992.

PORTELLI, A. Tentando aprender um pouquinho. Algumas reflexões sobre a ética na história oral. Projeto História. São Paulo, n. 15, abr./1997, p. 13-49.

SCOTT, J.C. Weapons of the weak: everyday forms of peasant resistance. Massachusets: Yale University, 1985.

Domination and the arts of resistance: hidden transcripts. New Haven / London: Yale University Press, 1990. 
THOMPSON, E. P. A miséria da teoria. São Paulo: Brasiliense / UNESP, 1981.

THOMSON, A. Aos cinqüenta anos: uma perspectiva internacional da história oral. In: FERREIRA, M. M. et al. História oral: desafios para o século XXI. Rio de Janeiro: Ed. Fiocruz / Ed. FGV, 2000, p. 47-65.

WILLEMS, E. Vida brasileira: tradição e transição. São Paulo: Difusão Européia do Livro, 1961.

WOORTMANN, K.; WOORTMANN, E. Fuga a três vožes. Brasília: UnB / Depto.de Antropologia, 1992. (Série Antropologia, 129)

Resumo: Este artigo pretende analisar as memórias de mulheres e homens em famílias camponesas do Agreste paraibano sobre namoro e casamento. A partir destas memórias, buscamos compreender as representações e práticas vinculadas ao habitus do grupo estudado, bem como as transgressões e as práticas de resistência às regras, modelos e valores sociais. Os homens e mulheres, além de narrarem a partir de sua posição de gênero, também se detêm de modo mais longo sobre determinados fatos, acontecimentos ou fases da vida; eles narram timidamente sobre namoro, sexualidade e casamento. Ao adotarmos a metodologia da história oral, entendemos que as entrevistas semi-estruturadas e histórias de vida realizadas não foram simples técnica ou instrumento de pesquisa, mas um discurso construído no processo de interação social entre pesquisador e informantes.

Palavras-chave: camponeses-migrantes; casamento; memória; narrativa.

Dating and marriage experiences among migrant peasants families

Abstract: This article intends to analyze the memories on dating and marriage of peasant families' men and women in Paraiba's heartland. We intend to grasp the representations and practices linked to the group's habitus, as well as the transgressions and resistance to social rules, models and values. Men and women, besides narrating from theirs gender standing point, pay more attention to certain life facts or periods; they're shy when talking about dating, sexuality and marriage. By adopting oral history methodology, we understand that life stories interviews, beneath being just a research tool, are a speech built on the social interaction process between researcher and informers.

Keywords: migrant-peasants; marriage; memory; narrative. 